\title{
Effects of feed intake on composition of sheep rumen contents and their microbial population size
}

\author{
C. A. Rodríguez ${ }^{1}$, J. González ${ }^{1}$, M. R. Alvir ${ }^{1}$, R. Redondo ${ }^{2}$ and C. Cajarville ${ }^{1} \dagger$ \\ ${ }^{1}$ Departamento de Producción Animal, Universidad Politécnica de Madrid, 28040 Madrid, Spain \\ ${ }^{2}$ Servicio Interdepartamental de Investigación, Universidad Autónoma de Madrid, 28049 Madrid, Spain
}

(Received 8 November 2001 - Revised 6 August 2002 - Accepted 6 September 2002)

\begin{abstract}
The present study was conducted to determine the effect of feed intake on the composition of the rumen contents of sheep and on their bacterial densities. Whole rumen contents were sampled after a period of continuous inter-rumen infusion of ${ }^{15} \mathrm{NH}_{3}$ from four rumencannulated wethers successively fed on a hay-concentrate diet $(2: 1, \mathrm{w} / \mathrm{w}$ on a DM basis) at two rates of feed intake: 40 and $80 \mathrm{~g} \mathrm{DM} / \mathrm{kg}$ body weight ${ }^{075}$. Total weight and chemical composition of rumen contents, as well as the distribution by size and chemical composition of particles, were determined. The populations of bacteria associated with the liquid (liquidassociated bacteria, LAB) and solid (solid-associated bacteria, SAB) fractions of rumen digesta and the distribution of SAB according to feed particle size were also examined. The greater feed intake caused an increase in the mass of the rumen contents, while its chemical composition did not change, except for a higher content of organic matter $(P=0 \cdot 023)$. The distribution of feed particles by size was similar at both levels of intake. The concentrations of neutral- and acid-detergent fibre in feed particles decreased and those of total, dietary, and microbial $\mathrm{N}$ increased, both with a quadratic response $(P=0 \cdot 001)$, as particle size decreased. The proportion of LAB in the microbial biomass of rumen digesta reached only $8.0 \%$. This proportion and the density of LAB were unaffected by the level of feed intake, whereas an apparent reduction $(10.4 \%)$ occurred with the SAB biomass in whole rumen contents. A systematic, but not significant, reduction (mean value $11.9 \%$ ) in the level of microbial colonisation in the different particle fractions with the increase of feed intake was also observed.
\end{abstract}

Rumen contents: Chemical composition: Feed intake: Microbial population size

Increasing levels of feed intake raises the weight of the rumen contents and/or its rumen outflow rate (Ellis et al. 1984). In addition, the level of feed intake affects the rumination and, therefore, the particle distribution of rumen digesta (Bae et al. 1979). Rumen outflow rate, composition of rumen contents and particle distribution are factors that may affect the microbial growth and density, and therefore the efficiency of the microbial synthesis and the microbial contribution to the post-rumen nutrient flow. The effect of the intake level on the efficiency of microbial synthesis is considered in the metabolisable protein system (Agricultural and Food Research Council, 1992) through the influence of the plane of feeding. Nevertheless, the effects of feed intake on the microbial density of rumen contents have received little attention, in spite of their possible influence on the microbial growth and on microbial degradative actions on the feeds.
Bacteria in rumen digesta are composed of two different populations: liquid-associated bacteria (LAB) and solidassociated bacteria (SAB), with different chemical compositions (Merry \& McAllan, 1983). Some of the differences are related to compounds used as internal (diaminopimelic acid, nucleic acids or purines) or external $\left({ }^{15} \mathrm{~N},{ }^{35} \mathrm{~S}\right)$ microbial markers. Greater marker: $\mathrm{N}$ ratios have been observed systematically for $\mathrm{LAB}$ compared with $\mathrm{SAB}$ for all these markers (Merry \& McAllan, 1983; Martin et al. 1994; Benchaar et al. 1995; Rodríguez et al. 2000). For practical reasons, microbial synthesis in the rumen has usually been calculated using marker: $\mathrm{N}$ ratios determined in $\mathrm{LAB}$, even though these bacteria only represent a small fraction of the total bacterial population (Czerkawski \& Breckenridge, 1982; Legay-Carmier \& Bauchard, 1989). The importance of the resultant under-evaluation of microbial synthesis is logically dependent on the LAB:SAB ratio in

\footnotetext{
Abbreviations: ADF, acid-detergent fibre; ADL, acid-detergent lignin; LAB, liquid-associated bacteria; NAN, non-ammonia-nitrogen; NDF, neutraldetergent fibre; $\mathrm{OM}$, organic matter; $\mathrm{SAB}$, solid-associated bacteria.

* Corresponding author: Dr C. A. Rodríguez, fax +34 91 5499763, email crodriguez@pan.etsia.upm.es

$\dagger$ Present address: Departamento de Nutrición Animal, Universidad de la Republica Oriental del Uruguay, 11600 Montevideo, Uruguay.
} 
the rumen outflow. Therefore, this under-evaluation can be derived from the same ratio in rumen digesta and from the ratio between the outflow rates of its respective associated phases. The proportions of $\mathrm{LAB}$ and $\mathrm{SAB}$ in the rumen show a large variation (Legay-Carmier \& Bauchart, 1989; Martin \& Michalet-Doreau, 1995), which suggests the need for further research on the proportions of both bacterial populations.

The purpose of the present study was to determine the effect of the feed intake on: (1) the weight, chemical composition and particle distribution by size of the rumen contents; (2) the extent of microbial attachment in relation to particle size; (3) the microbial cell density in the liquid and solid phases of rumen digesta.

\section{Materials and methods}

Animals and feeding

Four wethers (average body weight $62.2 \mathrm{~kg}$ ) equipped with detachable rumen fistulas (inner diameter $80 \mathrm{~mm}$ ) were fed a diet composed of chopped vetch (Vicia sativa)-oat (Avena sativa) hay $(55: 45, \mathrm{w} / \mathrm{w})$ and concentrate (hayconcentrate $2: 1$, w/w on a DM basis). The concentrate contained $(\mathrm{g} / \mathrm{kg})$ : maize 607 , dehydrated beet pulp 300 , soyabean meal 45 , fishmeal 20 , bentonite 15 , minerals and vitamins 13 . This diet was offered as six meals per $\mathrm{d}$, at intervals of $4 \mathrm{~h}$. Two successive experimental periods comparing two rates of DM intake were carried out. In the first, all wethers were fed at $40 \mathrm{~g} \mathrm{DM} / \mathrm{kg}$ body weight ${ }^{0.75}$ and in the second, at $80 \mathrm{~g} \mathrm{DM} / \mathrm{kg}$ body weight ${ }^{0.75}$, representing $90 \%$ of the voluntary intake of these animals as measured previously. Both rates of feed intake represent $1 \cdot 1$ - and 2.2-times energy maintenance requirements. The chemical compositions of hay and concentrate were described in a previous study (Rodríguez et al. 2000).

\section{Experimental procedures}

After a $14 \mathrm{~d}$ period of adaptation to the diet, the rumen micro-organisms were labelled with a $50 \%$ enriched $\left({ }^{15} \mathrm{NH}_{4}\right)_{2} \mathrm{SO}_{4}$ solution (ICON Service Inc., Mt. Marion, NY, USA) to determine the microbial colonisation of feeds (Rodríguez et al. 1999), the chemical composition of bacteria (Rodríguez et al. 2000) and the bacterial population size. This solution $(200 \mathrm{mg} \mathrm{N} / \mathrm{l})$ was continuously infused into the rumen for at least $30 \mathrm{~d}$ at a rate of $400 \mathrm{ml} / \mathrm{d}$. After this period, the total reticulo-rumen content was obtained by manual emptying, just before the first morning meal. To avoid a bias between the liquid and solid phases during sampling, when emptying, the rumen contents were squeezed through a nylon cloth (pore size $200 \mu \mathrm{m}$ ) and the liquid and solid fractions were weighed and recorded. Immediately, both fractions were homogenised and grab samples were taken to reconstitute (by weight) three samples of 200 (sample A), 500 (sample B) and 1200 (sample C) g. Finally, the remaining fractions of solid and liquid were reintroduced into the rumen.

Sample A was freeze-dried and used to determine chemical composition. Analyses of organic matter (OM), $\mathrm{N}$, non- $\mathrm{NH}_{3}-\mathrm{N}$ (NAN), neutral-detergent fibre (NDF), acid-detergent fibre (ADF), acid-detergent lignin (ADL) and ${ }^{15} \mathrm{~N}$ abundance $\left({ }^{15} \mathrm{~N}: \mathrm{N}\right)$ were performed.

Sample B was squeezed through a double layer of nylon cloth (pore size $46 \mu \mathrm{m}$ ). The solid and liquid phases obtained were weighed and their relative proportions recorded. Next, several subsamples were composed (by weight) in accordance with these proportions, as follows: (1) two samples of $2 \mathrm{~g}$ each (with the addition of $0.8 \mathrm{ml}$ $0.4 \mathrm{M}-\mathrm{HCl}$ as preservative) for analyses of $\mathrm{NH}_{3}-\mathrm{N}$ concentration and its ${ }^{15} \mathrm{~N}$ abundance; (2) two samples of $50 \mathrm{~g}$ each for the determination of the DM content (oven-dried for $24 \mathrm{~h}$ at $40^{\circ} \mathrm{C}$ and subsequently for $24 \mathrm{~h}$ at $80^{\circ} \mathrm{C}$ ); (3) two samples of $150 \mathrm{~g}$ each, processed through wet sieving, to determine the particle size distribution. Sieves $(200 \mathrm{~mm}$ internal diameter) with square meshes of 2.500, 1.250, $0.630,0.315,0.160$ and $0.080 \mathrm{~mm}$ on a side were used in an electromagnetic sieve shaker (Model 200; Filtra SA, Barcelona, Spain) with a flow of 2 litres saline solution $(9 \mathrm{~g} \mathrm{NaCl} / \mathrm{l}$ distilled water $) / \mathrm{min}$. The different sieves were removed 15, 20, 24, 27, 29 and $30 \mathrm{~min}$ respectively after the beginning of the sieving process. The sieves were each dried at room temperature $\left(20-22^{\circ} \mathrm{C}\right)$ for $1 \mathrm{~h}$, transferred to an oven $\left(24 \mathrm{~h}\right.$ at $40^{\circ} \mathrm{C}$ then $24 \mathrm{~h}$ at $80^{\circ} \mathrm{C}$ ) and weighed to determine the DM retained. Samples from each pore size were analysed for NDF, ADF, ADL, N and ${ }^{15} \mathrm{~N}$ abundance.

Sample $\mathrm{C}$ was squeezed as indicated earlier and used for bacterial isolation and quantification. Retained particles (enclosed in the cloth) were subjected to three successive cycles of washing and shaking in a total volume of $700 \mathrm{ml}$ saline solution $(9 \mathrm{~g} \mathrm{NaCl} / 1$ distilled water $)$ at $4-5^{\circ} \mathrm{C}$ in order to remove trapped-fluid-associated microorganisms. The rumen liquid and saline wash fractions obtained were subjected to double centrifugation (Barr et al. 1975) to obtain LAB samples. The total bacterial pellets were lyophilised, weighed and analysed for DM and N. SAB were isolated from the washed solid phase and from the precipitate resulting from the first slow centrifugation during LAB isolation. Prior to isolation, one in eight of these samples were lyophilised, pooled and subjected to determinations of DM, N and ${ }^{15} \mathrm{~N}$ abundance. The remaining materials were re-suspended in saline solution $(9 \mathrm{~g} \mathrm{NaCl} / \mathrm{l} ; 2$ litres $/ \mathrm{kg})$ and homogenised. The homogenate was pummelled for $6 \mathrm{~min}$ in a stomacher and squeezed as described earlier for samples B and C. SAB were isolated from this liquid by the double centrifugation method described earlier. The bacterial pellets obtained were lyophilised and subjected to the same determinations. Proportions of $\mathrm{N}$ and $\mathrm{DM}$ from $\mathrm{SAB}$ in the total particulate phase, or in its fractions, were determined as follows:

SAB- $\mathrm{N}(\%)=\left({ }^{15} \mathrm{~N}\right.$ excess in $\mathrm{PP} /{ }^{15} \mathrm{~N}$ excess in $\left.\mathrm{SAB}\right)$

$$
\times 100
$$

and

SAB-DM $(\%)=$ SAB-N $(\%)$

$$
\times \frac{(\mathrm{N} \text { concentration in } \mathrm{PP} / \mathrm{N})}{\text { concentration in } \mathrm{SAB}},
$$

where PP is the particulate phase. 
The ${ }^{15} \mathrm{~N}$ excess was calculated assuming a natural abundance of 0.3663 atom\%.

\section{Analytical procedures}

The analytical procedures used to determine the chemical composition of the rumen contents (DM, OM and N) were those described by the Association of Official Analytical Chemists (1984). Fibre fractions were determined as indicated by Robertson \& Van Soest (1981). N isotopic proportions in SAB, LAB and rumen digesta were analysed by isotope-ratio MS (VG Prism II IRMS; VS Isotech, Warrington, Ches., UK) linked in series to a Dumasstyle N analyser EA 1108 (Carlo Erba Instruments, Milan, Italy). The $\mathrm{NH}_{3}$ concentration was measured by distillation with $10 \mathrm{ml}$ sodium tetraborate $(25 \mathrm{~g} / \mathrm{l})$ in boric acid $(10 \mathrm{~g} / \mathrm{l})$ and titration with $0.01 \mathrm{M}-\mathrm{HCl}$.

\section{Statistical analysis}

Results were subjected to ANOVA using a simple complete block experimental design, except for the results of the chemical composition of the different particle size fractions, for which a split-plot arrangement of treatments was used. In this case, the feed intake (low $v$. high) was considered as the whole-plot treatment and was tested using animal $\times$ feed intake interaction as the error term. Pore size and its interaction with the feed intake were the sub-plot treatments. Since animals were adult, feedrestricted and maintained in a controlled environment, the period effect was assumed to be negligible. All statistical analyses were performed using the Statistical Analysis System for Windows software (version 6.12; SAS Institute Inc., Cary, NC, USA).

\section{Results}

Weight and chemical composition of the rumen contents

The rumen contents, expressed per $\mathrm{kg}$ body weight ${ }^{0.75}$, increased significantly with the rise of feed intake both in terms of fresh matter $(P<0.016)$ or DM $(P<0.028)$ (Table 1). DM concentration and the proportion of the solid phase in rumen digesta were not affected by the increase in feed intake.

Most of the differences in the chemical composition of the rumen digesta (Table 2) were not significant, except for a higher content of $\mathrm{OM}(P=0 \cdot 023)$ and a decrease in

Table 1. Effect of feed intake on DM distribution in total rumen contents* (Mean values with their standard errors for four sheep)

\begin{tabular}{lcccc}
\hline & \multicolumn{2}{c}{ Feed intake† } & & \\
\cline { 2 - 3 } Item & Low & High & SEM & Statistical significance of effect: $P$ \\
\hline Fresh matter $\left(\mathrm{g} / \mathrm{W}^{0.75}\right)$ & 215 & 303 & 12.4 & 0.016 \\
DM $\left(\mathrm{g} / \mathrm{W}^{0.75}\right)$ & 25.0 & 38.5 & 2.39 & 0.028 \\
DM (\%) & 11.7 & 12.7 & 0.33 & 0.121 \\
Solid phase (\%)‡ & 49.5 & 53.8 & 2.20 & 0.261 \\
\hline
\end{tabular}

W, weight.

* For details of diets and procedures, see pp. 98, 99

† Low, $40 \mathrm{~g} \mathrm{DM} / \mathrm{kg}$ body weight ${ }^{0.75}$; high, $80 \mathrm{~g} \mathrm{DM} / \mathrm{kg}$ body weight ${ }^{0.75}$

‡ Squeezed through a nylon cloth (pore size $46 \mu \mathrm{m}$ ).

Table 2. Effect of feed intake on the chemical fractions of rumen contents and their mean rumen retention times ${ }^{*}$

(Mean values with their standard errors for four sheep)

\begin{tabular}{|c|c|c|c|c|}
\hline \multirow[b]{2}{*}{ Item } & \multicolumn{2}{|c|}{ Feed intake } & \multirow[b]{2}{*}{ SEM } & \multirow[b]{2}{*}{ Statistical significance of effect: $P$} \\
\hline & Low & High & & \\
\hline \multicolumn{5}{|c|}{ Chemical composition (\% DM) } \\
\hline Organic matter & 84.9 & $88 \cdot 0$ & 0.51 & 0.023 \\
\hline Neutral-detergent fibre & 51.9 & $55 \cdot 9$ & $1 \cdot 10$ & 0.086 \\
\hline Acid-detergent fibre & $29 \cdot 6$ & 33.7 & 1.44 & 0.137 \\
\hline Acid-detergent lignin & 7.44 & 7.05 & 0.30 & 0.424 \\
\hline Non- $\mathrm{NH}_{3}-\mathrm{N}(\times 6 \cdot 25)$ & $22 \cdot 5$ & $21 \cdot 2$ & 0.40 & 0.113 \\
\hline${ }^{15} \mathrm{~N} / \mathrm{Non}-\mathrm{NH}_{3}-\mathrm{N}(\%)$ & 0.496 & 0.436 & 0.006 & 0.005 \\
\hline \multicolumn{5}{|l|}{ Mean retention time $(\mathrm{h})$} \\
\hline Organic matter & $14 \cdot 5$ & 11.5 & 0.78 & 0.076 \\
\hline Neutral-detergent fibre & $20 \cdot 4$ & $16 \cdot 9$ & 1.34 & 0.161 \\
\hline Acid-detergent fibre & $19 \cdot 5$ & $17 \cdot 2$ & 1.66 & 0.399 \\
\hline Acid-detergent lignin & $36 \cdot 6$ & $26 \cdot 5$ & 1.42 & 0.015 \\
\hline Non- $\mathrm{NH}_{3}-\mathrm{N}$ & $25 \cdot 0$ & $17 \cdot 2$ & 0.92 & 0.010 \\
\hline${ }^{15} \mathrm{~N}$ & $22 \cdot 6$ & $16 \cdot \overline{7}$ & 0.90 & 0.021 \\
\hline
\end{tabular}

${ }^{*}$ For details of diets and procedures, see pp. 98, 99

† Low, $40 \mathrm{~g} \mathrm{DM} / \mathrm{kg}$ body weight ${ }^{0.75}$; high, $80 \mathrm{~g} \mathrm{DM} / \mathrm{kg}$ body weight ${ }^{0.75}$ 
the ${ }^{15} \mathrm{~N}: \mathrm{NON}-\mathrm{NH}_{3}-\mathrm{N}$ ratio $(P=0.005)$ at the higher intake. Nevertheless, the decrease was associated with the methodology employed, as the marker infusion dose was the same for both rates of feed intake. Table 2 also shows the mean retention time $(\mathrm{h})$ in the rumen of the corresponding chemical fractions calculated as the amount present in the reticulo-rumen:daily intake. The higher feed intake produced a generally lower mean retention time with the different chemical variables, this effect being significant only for $\mathrm{NAN},{ }^{15} \mathrm{~N}$ abundance and $\mathrm{ADL}(P=0.010$, $P=0.021$ and $P=0.015$ respectively).

\section{Distribution by size, chemical composition and bacterial colonisation of rumen particles}

The distribution of particle size in rumen contents (Table 3) was not markedly affected by the higher feed intake, although a trend towards a higher proportion of mediumsize particles (retained in sieves between 0.630 and $1.250 \mathrm{~mm}$ ) was detected. This increase was balanced by a trend towards a decrease $(P=0.084)$ in the proportion in the effluent fraction $(<0.080 \mathrm{~mm})$, consisting of very small particles, free micro-organisms and substances dissolved in the liquid phase.

The level of feed intake did not affect the chemical composition or the SAB content of particles, expressed in terms of $\mathrm{DM}$ or $\mathrm{N}$. The feed intake $\times$ sieve size interaction was not significant either. These results were thus pooled for both levels of intake. In contrast, the sieve size presented a strong and quadratic effect $(P<0.001)$ on the bacterial colonisation of particles and on most chemical components, except ADL. The evolution of these variables is presented in a logarithmic scale in Figs 1 and 2. The concentration of NDF and ADF in particles (Fig. 1(a)) showed a progressive reduction with the decrease in particle size. In contrast, the concentration of $\mathrm{N}$ (Fig. 1(b)) showed an increase, with the minimum value at the $1.250 \mathrm{~mm}$ sieve size. A similar progression was detected for the feed $\mathrm{N}$ concentration in particles, but with the minimum value corresponding to the $0.630 \mathrm{~mm}$ sieve size.

Even if, as indicated earlier, the bacterial biomass was not significantly affected by the level of feed intake, systematically lower values were observed for the high feed intake (mean value $11.9 \%$ ). In contrast, no difference was found in the proportion of total $\mathrm{N}$ in particles
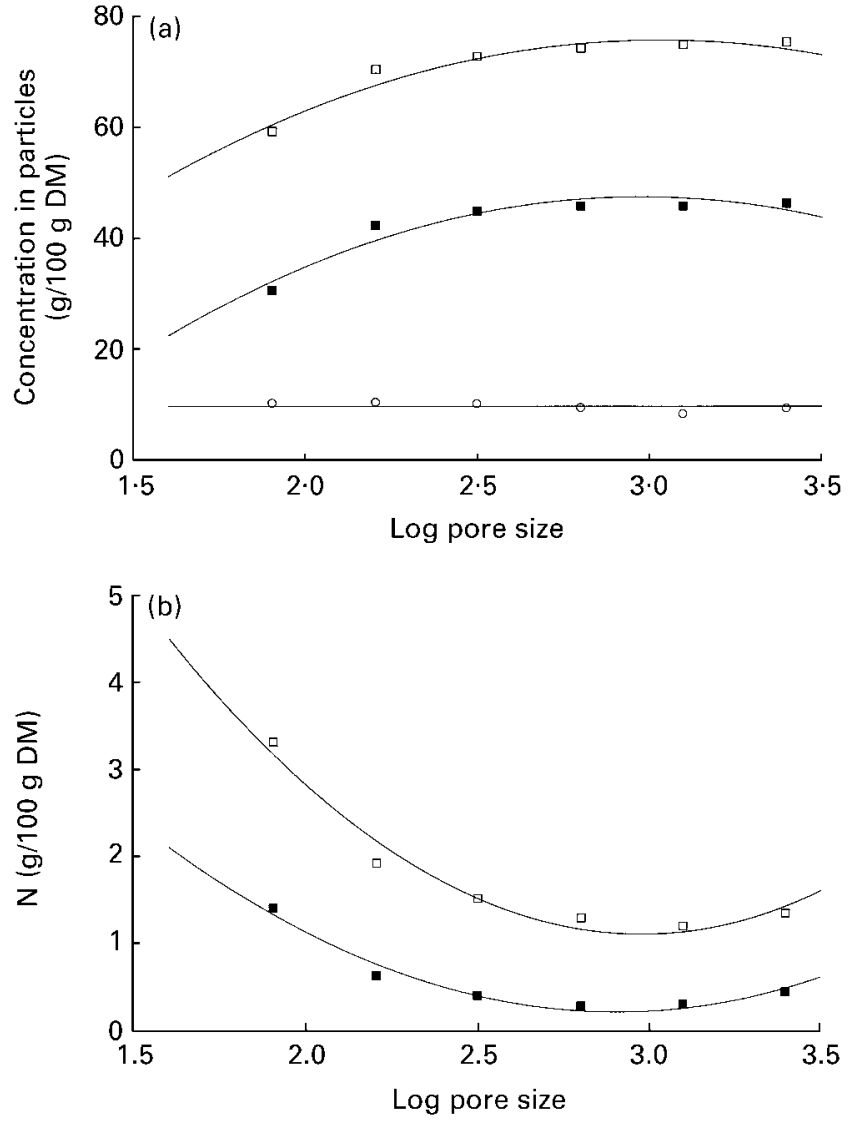

Fig. 1. Relationships between the particle size (logarithm of the pore size $(p, \mu m))$ of rumen contents and the concentration in particles $(g / 100 \mathrm{~g} D M)$ of (a) neutral-detergent fibre (NDF, $\square$ ), aciddetergent fibre (ADF, $\mathbf{a}$ ) and acid-detergent lignin (ADL, $O$ ) or (b) total $N(\square)$ and feed $N(\square)$. For details of diets and procedures, see pp. 98, 99. Regression equations were: NDF $=-36.1+73.2 \times \mathrm{p}-$ $12.1 \times \mathrm{p}^{2} \quad\left(\mathrm{RSD} 2.95, \quad R^{2} \quad 0.795, \quad P<0.001, \quad n \quad 48\right) ; \quad \mathrm{ADF}=$ $-72.1+79.5 \times \mathrm{p}-13.4 \times \mathrm{p}^{2}$ (RSD 2.66, $\left.R^{2} 0.827, P<0.001, n 48\right)$; total $\mathrm{N}=17-10.7 \times \mathrm{p}+1.79 \times \mathrm{p}^{2}\left(\mathrm{RSD} 0.21, R^{2} 0.927, P<0.001\right.$, $n$ 48); feed $\mathrm{N}=9.46-6.47 \times \mathrm{p}+1.12 \times \mathrm{p}^{2}$ (RSD 0.13, $R^{2} 0.909$, $P<0.001, n$ 48).

coming from bacteria (mean values 693 v. $698 \mathrm{mg}$ SAB-N/g $\mathrm{N}$ for low and high feed intake respectively). Bacterial biomass showed a progressive increase with the reduction of the sieve size. However, when this value was expressed in terms of $\mathrm{N}$, the maximum values were recorded for the $0.630 \mathrm{~mm}$ sieve size (Fig. 2).

Table 3. Effect of feed intake on the particle size distribution (\% DM) of rumen contents* (Mean values with their standard errors for four sheep)

\begin{tabular}{lccccccc}
\hline & \multicolumn{7}{c}{ Pore size $(\mathrm{mm})$} \\
\cline { 2 - 9 } Feed intaket & $<0.080$ & 0.080 & 0.160 & 0.315 & 0.630 & 1.250 & 2.500 \\
\hline Low & 35.7 & 7.30 & 9.00 & 12.6 & 11.1 & 4.41 & 19.8 \\
High & 32.8 & 6.40 & 9.15 & 13.0 & 13.5 & 5.77 & 19.4 \\
SEM & 0.81 & 0.40 & 0.38 & 0.31 & 0.56 & 0.30 & 1.14 \\
Statistical significance of effect: $P$ & 0.084 & 0.206 & 0.799 & 0.393 & 0.060 & 0.052 & 0.838
\end{tabular}

* For details of diets and procedures, see pp. 98, 99.

† Low, $40 \mathrm{~g} \mathrm{DM} / \mathrm{kg}$ body weight ${ }^{0.75}$; high, $80 \mathrm{~g} \mathrm{DM} / \mathrm{kg}^{\text {body }}$ weight ${ }^{0.75}$. 


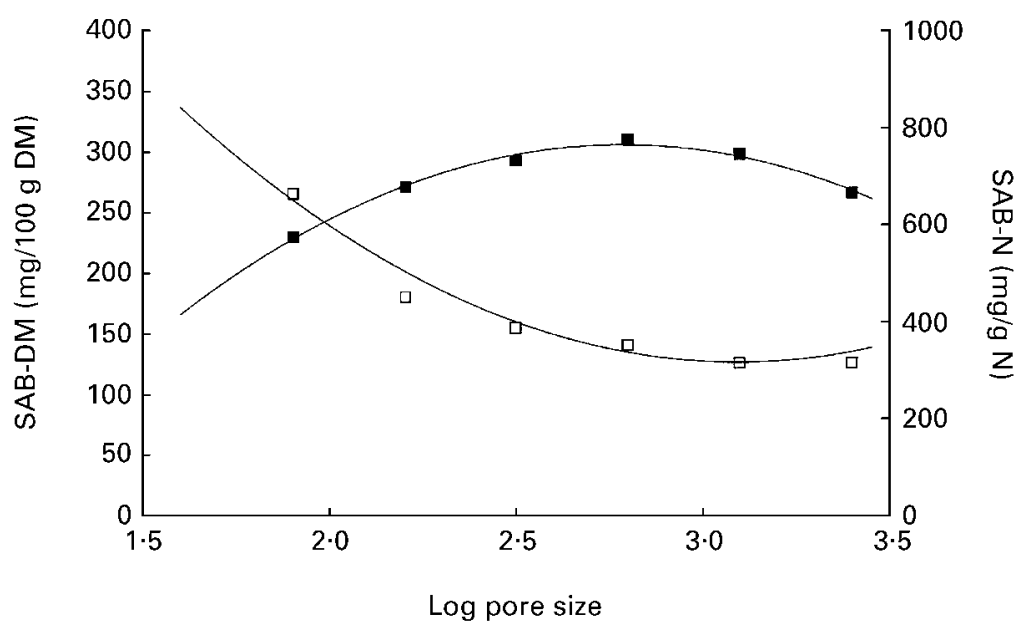

Fig. 2. Relationships between the particle size (logarithm of the pore size $(p, \mu \mathrm{m})$ of rumen contents and the solid-associated bacteria (SAB) content of particles in terms of DM (mg SAB-DM/ $100 \mathrm{~g} \mathrm{DM} ; \square)$ and N (mg SAB-N/g N; $\mathbf{\square})$. For details of diets and procedures, see pp. 98, 99. Regression equations were: $\mathrm{SAB}-\mathrm{DM}=1040.9-585.9 \times \mathrm{p}+94.7 \times \mathrm{p}^{2} \quad\left(\mathrm{RSD} 21.8, R^{2} 0.848, P<0.001, n 48\right) ; \mathrm{SAB}-\mathrm{N}=-1101.3+$ $1395.4 \times \mathrm{p}-250.5 \times \mathrm{p}^{2}\left(\mathrm{RSD} 53.0, R^{2} 0.747, P<0.001, n 48\right)$.

\section{Microbial population distribution and size}

Table 4 shows the mean values of the content and density of bacteria in rumen digesta for both rates of feed intake. A significant increase of the absolute SAB fraction, both expressed in terms of $\mathrm{DM}$ or $\mathrm{N}(P=0.015$ and $P=0.006$ respectively), was observed with the higher feed intake. The LAB fraction, expressed in the same terms, also gave higher values with the increase in the feed intake, although the differences were not significant in this case. The proportion of the LAB fraction (approximately $8.0 \%)$ and its density in the liquid phase were the same for both feed intakes. In the solid phase, a moderate but non-significant decrease $(10.4 \%)$ of the SAB biomass was recorded at the higher feed intake. In contrast, the proportions of $\mathrm{N}$ from $\mathrm{SAB}$ were similar. The same trend was observed in both variables for the sum of SAB and $\mathrm{LAB}$ in whole rumen contents.

\section{Discussion}

The higher feed intake led, in the present study, to an increase in the rumen repletion and also of the rumen outflow rate (Rodríguez et al. 2000) as a result of the higher rumen pressure and rumination activity. These effects agree with findings by several authors (Minson, 1966; Aitchison et al. 1986; Robinson et al. 1987).

The only significant effect on the chemical composition was the increase in \% OM $(P=0.023)$, which agrees with results obtained by Robinson et al. (1987). This variation can be attributed to the decrease in the ash concentration

Table 4. Effect of feed intake on the bacterial biomass associated with the solid (SAB) and liquid (LAB)-associated bacteria phases of rumen contents*

(Mean values with their standard errors for four sheep)

\begin{tabular}{|c|c|c|c|c|}
\hline Feed intake...† & Low & High & SEM & Statistical significance of effect: $P$ \\
\hline \multicolumn{5}{|l|}{ Total LAB in rumen contents } \\
\hline DM (g) & $15 \cdot 4$ & $19 \cdot 6$ & $2 \cdot 20$ & 0.268 \\
\hline$N(g)$ & 1.06 & 1.40 & $0 \cdot 15$ & $0 \cdot 614$ \\
\hline \multicolumn{5}{|l|}{ Total SAB in rumen contents } \\
\hline DM (g) & 174 & 234 & $8 \cdot 39$ & 0.015 \\
\hline$N(g)$ & $12 \cdot 2$ & $17 \cdot 0$ & 0.48 & 0.006 \\
\hline \multicolumn{5}{|l|}{$\mathrm{LAB}$ proportion $(\mathrm{LAB} /(\mathrm{LAB}+\mathrm{SAB}))$} \\
\hline$\%$ DM & 8.06 & $7 \cdot 88$ & $1 \cdot 19$ & 0.924 \\
\hline$\% \mathrm{~N}$ & $7 \cdot 91$ & $7 \cdot 68$ & 1.07 & 0.887 \\
\hline \multicolumn{5}{|l|}{ Microbial density } \\
\hline LAB-DM (g)/kg liquid phase & 4.83 & $4 \cdot 84$ & 0.71 & 0.999 \\
\hline SAB-DM $(\mathrm{g}) / \mathrm{kg}$ solid phase-DM & 375 & 336 & $16 \cdot 3$ & 0.188 \\
\hline SAB-N (mg)/g NAN $\ddagger$ & 782 & 773 & $38 \cdot 1$ & 0.889 \\
\hline$(S A B+L A B)-D M(g) / k g$ rumen contents $D M$ & 336 & 295 & $16 \cdot 0$ & 0.168 \\
\hline$(\mathrm{SAB}+\mathrm{LAB})-\mathrm{N}(\mathrm{mg}) / \mathrm{g}$ NANß & 817 & 813 & $29 \cdot 9$ & 0.942 \\
\hline
\end{tabular}

$\mathrm{NAN}$, non- $\mathrm{NH}_{3}-\mathrm{N}$

${ }^{*}$ For details of diets and procedures, see pp. 98, 99.

† Low, $40 \mathrm{~g} \mathrm{DM} / \mathrm{kg}$ body weight ${ }^{0.75}$; high, $80 \mathrm{~g} \mathrm{DM} / \mathrm{kg}$ body weight ${ }^{0.75}$

$\ddagger$ NAN from the solid phase of rumen contents.

§NAN from the whole rumen contents. 
of bacteria observed in the same experiment $(18 \mathrm{mg} / \mathrm{g}$; Rodríguez et al. 2000) and to the reduction (Table 4) of the rumen bacterial density. Thus, both factors together explain $92 \%$ of the observed variation in rumen OM.

The lower reductions observed for the rumen mean retention time for $\mathrm{ADF}(11.8 \%)$ and $\mathrm{NDF}(17.2 \%)$ than for $\mathrm{ADL}(27.6 \%)$, which can only disappear from the rumen by transit, showed a reduction in the extent of fibre degradation with the increase in feed intake. This observation was confirmed by a significant depression of the fractional degradation rate of the ADF (39.4\%) and of the NDF (27\%) in the vetch-oat hay in the diet (results not shown). The reduction in mean retention time observed in $\mathrm{N}$, and especially in ${ }^{15} \mathrm{~N}$, is in agreement with a reduction of internal recycling of $\mathrm{N}$ in the rumen associated with a lower micro-organism lysis and a higher efficiency of microbial protein synthesis, as observed elsewhere (Hespell \& Bryant, 1979; Harrison \& McAllan, 1980; Ørskov, 1988) as a consequence of the acceleration of the rumen outflow.

The low variation observed between both rates of feed intake on the distribution of particles by size (Table 3) agrees with the results obtained by Kovács et al. (1997). Nevertheless, the trends detected may also indicate that rumination was slightly less efficient at the higher rate, which agrees with results of Bae et al. (1979).

The quadratic reductions of the NDF and ADF concentrations with decreasing particle size (Fig. 1(a)) suggests that particles $>0.630 \mathrm{~mm}$ come mainly from the hay, while in those of smaller size, the proportion of particles coming from the concentrate increased progressively. This scheme is based on the constancy of the NDF and ADF concentrations in particles $>0.630 \mathrm{~mm}$; these concentrations (ranging from 74.3 to $75.5 \%$ and from 45.8 to $46.3 \%$ for NDF and ADF respectively) were similar to those in the insoluble DM fraction of the original hay (73.9 and $46.2 \%$ for NDF and ADF respectively). The progressive decrease obtained with the reduction of particle size $<0.630 \mathrm{~mm}$ is in accordance with the lower concentration in fibre in the raw materials of the concentrate.

The quadratic increase $(P<0.001)$ in the microbial biomass in particles as their size decreased (Fig. 2) may be attributed to the cumulative microbial colonisation associated with the increase in the rumen residence time derived from the process of particle comminution. On the other hand, this latter process increases the particle surface and the damaged areas on the plant tissues, increasing the possibilities of microbial adhesion and colonisation (Cheng et al. 1984; Pond et al. 1984). Legay-Carmier \& Bauchart (1989) did not detect differences in the microbial content of particles retained by different sieves, but observed a great increase in the bacterial DM content of the effluent not retained by a pore size of $0.100 \mathrm{~mm}$. These results partially agree with our present findings, in which the main part of the detected effect was observed in the smallest particles, which is in turn in agreement with the results obtained in vitro by Gerson et al. (1988). The main role of comminution on the bacterial content of feed particles was also reinforced by the inverse trend of the bacterial and fibre contents in relation to particle size, in spite of the fact that fibre can be considered as the main substrate for bacterial adherence (Michalet-Doreau \& Ould Bah, 1989; Rodríguez et al. 1999).

The proportions of free bacteria (mean value $8.0 \%$ ) showed that these micro-organisms constituted a small fraction of the rumen biomass, which agrees with the value of $10 \%$ obtained by Czerkawski \& Breckenridge (1982). Our present results also support other studies, where SAB were largely predominant in the bacterial biomass (Legay-Carmier \& Bauchart, 1989; Martin \& Michalet-Doreau, 1995). However, determinations of SAB are always carried out indirectly, due to the impossibility of releasing all adherent bacteria from particles. In this respect, other types of adherent micro-organisms are considered as bacteria in these studies. In addition, in the present experiment, the sample used to calculate the total SAB content included the pellet collected from the first centrifugation of the liquid phase, which contains the non-adherent protozoa. Therefore, in this sample, SAB values tend to be an estimate of the whole microbial biomass of digesta, excluding free bacteria. For the microbial markers most usually employed to measure microbial synthesis (diaminopimelic acid, purines, ${ }^{15} \mathrm{~N}$ ) the marker: $\mathrm{N}$ ratio is higher in LAB than in SAB (Merry \& McAllan, 1983; Martin et al. 1994; Benchaar et al. 1995; Rodríguez et al. 2000). Therefore, its use as reference sample of rumen micro-organisms leads to an important underestimate of rumen microbial protein flow and of the efficiency of the microbial synthesis.

The results of the present research also showed that the higher feed intake had no effect on the proportion of free bacteria in the total microbial biomass or on their density in the liquid phase. In contrast, the microbial density of the particulate matter may decrease with the higher feed intake. Thus, the apparent reduction in the microbial density in the total solid phase $(10.4 \%)$ was also observed systematically in all the particle size fractions (mean reduction $11.9 \%$ ). Nevertheless, the flow of microbial $\mathrm{N}$ leaving the rumen increased largely as a consequence of the higher rumen contents (Table 1), but also due to the increase in the liquid and solid outflow rates and in the $\mathrm{N}$ content of bacteria determined in the same experiment (Rodríguez et al. 2000), which is in agreement with the increase in microbial efficiency usually observed at higher feed intakes.

The microbial N:NAN ratio observed in the whole rumen contents as well as in the total solid phase showed that micro-organisms represented the main part of the nitrogenous compounds of rumen digesta. The value of this ratio was unaffected by the feed intake.

\section{Acknowledgements}

This work was supported by the CICYT funded Project GAN 89-0126. Analyses of ${ }^{15} \mathrm{~N}$ isotopic ratios were performed at the Servicio Interdepartamental de Investigación, Universidad Autónoma de Madrid.

\section{References}

Agricultural and Food Research Council (1992) Technical committee on responses to nutrients. Nutritive requirements of 
ruminant animals: protein. Report no. 9. Nutrition Abstracts and Reviews 62, 787-835, (Series B).

Aitchison EM, Gill M, Dhanoa MS \& Osbourn DF (1986) The effect of digestibility and forage species on the removal of digesta from the rumen and the voluntary intake of hay by sheep. British Journal of Nutrition 56, 463-476.

Association of Official Analytical Chemists (1984) Official Methods of Analysis, 14th ed, Arlington, VA: AOAC.

Bae DH, Welch JG \& Smith AM (1979) Forage intake and rumination by sheep. Journal of Animal Science 49, 1292-1299.

Barr GW, Bartley EE \& Meyer RM (1975) Feed processing. 8. Estimating microbial protein in rumen fluid with precipitating agents or in incubated mixtures of uncooked grain plus urea or starch with differential centrifugation. Journal of Dairy Science 58, 1308-1319.

Benchaar C, Bayourthe C, Vernay M \& Moncoulon R (1995) Composition chimique des bactéries libres ou adhérentes au contenu du rumen et du duodénum chez la vache (Chemical composition of bacteria free or attached to rumen or duodenum content in cows). Annales de Zootechnie 44, Suppl., 139.

Cheng KJ, Stewart CS, Dinsdale D \& Costerton JW (1984) Electron microscopy of bacteria involved in the digestion of plant cell walls. Animal Feed Science and Technology 10, 93-120.

Czerkawski JW \& Breckenridge G (1982) Distribution and changes in urease $(E C$ 3.5.1.5) activity in rumen simulation technique (Rusitec). British Journal of Nutrition 47, 231-348.

Ellis WC, Matis JH, Pond KR, Lascano CE \& Telford JP (1984) Dietary influences on flow rate and digestive capacity. In Herbivore Nutrition in the Subtropics and Tropics, pp. 269-293 [FMC Gilchrist and RI Machie, editors]. Johannesburg: The Science Press.

Gerson T, King ASD, Kelly KE \& Kelly WJ (1988) Influence of particle size and surface area on in vitro rates of gas production, lipolysis of triacylglycerol and hydrogenation of linoleic acid by sheep rumen digesta or Ruminococcus flavefaciens. Journal of Agricultural Science, Cambridge 110, 31-37.

Harrison DG \& McAllan AB (1980) Factors affecting microbial growth yields in the reticulo-rumen. In Digestive Physiology and Metabolism in Ruminants, pp. 205-226 [Y Ruckebusch and P Thivend, editors]. Lancaster: MTP Press Limited.

Hespell RB \& Bryant MP (1979) Efficiency of rumen microbial growth: influence of some theoretical and experimental factors on Y ATP. Journal of Animal Science 49, 1640-1659.

Kovács PL, Südekum K-H \& Stangassinger M (1997) Rumen contents and ruminal and faecal particle size distribution in steers fed a mixed diet at three amounts of intake. Animal Feed Science and Technology 64, 143-154.

Legay-Carmier F \& Bauchart D (1989) Distribution of bacteria in the rumen contents of dairy cows given a diet supplemented with soyabean oil. British Journal of Nutrition 61, 725-740.

Martin C \& Michalet-Doreau B (1995) Variations in mass and enzyme activity of rumen micro-organisms: Effect of barley and buffer supplements. Journal of the Science of Food and Agriculture 67, 407-413.

Martin C, Williams AG \& Michalet-Doreau B (1994) Isolation and characteristics of the protozoal and bacterial fractions from bovine ruminal contents. Journal of Animal Science 72, $2962-2968$.

Merry RJ \& McAllan AB (1983) A comparison of the chemical composition of mixed bacteria harvested from the liquid and solids fractions of rumen digesta. British Journal of Nutrition 50, 701-709.

Michalet-Doreau B \& Ould-Bah MY (1989) Estimation of the extent of bacterial contamination in bag residues and its influence on in sacco measurements of forage nitrogen degradation in the rumen. In Proceedings of the XVI International Grassland Congress, 4-11 October 1989, Nice, France, pp. 909-910 [AFPF, editor]. Versailles: Asociation Française pour la Production Fourragère.

Minson DJ (1966) The apparent retention of food in the reticulorumen at two levels of feeding by means of an hourly feeding technique. British Journal of Nutrition 20, 765-773.

Ørskov ER (1988) Nutrición proteica de los rumiantes (Protein nutrition in ruminants). Zaragoza: Acribia SA.

Pond KR, Ellis WC \& Akin DE (1984) Ingestive mastication and fragmentation of forages. Journal of Animal Science 58, $1567-1574$

Robertson JB \& Van Soest PJ (1981) The detergent system of analysis and its application to human foods. In The Analysis of Dietary Fiber in Food, pp. 123-158 [WPT James and O Theander, editors]. New York: Marcel Dekker Inc.

Robinson PH, Tamminga S \& van Vuuren AM (1987) Influence of declining level of feed intake and varying the proportion of starch in the concentrate on rumen ingesta quantity, composition and kinetics of ingesta turnover in dairy cows. Livestock Production Science 17, 37-62.

Rodríguez CA, González J, Alvir MR \& Repetto JL (1999) Microbial nitrogen contamination of in sacco ruminal incubated feeds. In Protein Metabolism and Nutrition. Book of Abstracts of the VIIIth International Symposium on Protein Metabolism and Nutrition, pp. 68 [GE Lobley, A White and JC MacRae, editors]. Wageningen: Wageningen Pers.

Rodríguez CA, González J, Alvir MR, Repetto JL, Centeno C \& Lamrani F (2000) Composition of bacteria harvested from the liquid and solid fractions of the rumen of sheep as influenced by intake level. British Journal of Nutrition 84, 369-376. 